\title{
Pengembangan Teknologi Air Bersih Masyarakat dalam Rangkaian Percepatan MDG's 2015 Di Kabupaten Malang
}

\author{
Aulia Ulfah Farahdiba ${ }^{1)}$; Annisa Ramdhaniati' ${ }^{2)}$ dan Eddy S. Soedjono ${ }^{2)}$ \\ ${ }^{1)}$ Environmental Engineering Department, National Cheng Kung University (NCKU), Tainan, Taiwan \\ 2) Jurusan Teknik Lingkungan, Institut Teknologi Sepuluh Nopember (ITS), Surabaya, Indonesia
}

\begin{abstract}
Abstrak
MDG's (Millenium Development Goal's) 2015 menjadi salah satu komitmen percepatan sanitasi yang harus dicapai di seluruh wilayah Indonesia. Kondisi pelayanan air bersih penduduk Indonesia masih tergolong kurang memenuhi aspek keberlanjutan di segi kualitas dan kuantitas. Selain itu, pemerataan pelayanan penyediaan air bersih masih kurang, terutama pada daerah perdesaan. Maka dalam rangka percepatan capaian akses air bersih di wilayah Indonesia, perlu adanya evaluasi dari aspek teknologi, sosial, dan budaya. Pada studi kasus program percepatan sanitasi, Kabupaten Malang, Desa Argosari menjadi salah satu kawasan strategis yang memiliki potensi sumber daya alam sebagai wilayah konservasi lingkungan dalam pelestarian hutan dan perlindungan air bersih. Sehingga memiliki potensi sumber air (mata air) yang berkualitas. Namun permasalahan yang yang terjadi, hampir seluruh masyarakat tidak memiliki akses air bersih yang layak. Sehingga, penerapan teknologi distribusi air bersih diaplikasikan untuk meningkatkan kapasitas penduduk yang terlayani dengan air bersih dan diharapkan dapat mempercepat capian sanitasi Indonesia di tahun 2015 .
\end{abstract}

Kata Kunci : Air bersih, sanitasi, Kabupaten Malang

\section{PENDAHULUAN}

Permasalahan lingkungan tidak terlepas dengan adanya permasalahan air bersih dan sanitasi yang berhubungan dengan keberlangsungan tingkat kesehatan masyarakat. Permasalahan ini sudah menjadi permasalahan global, hingga timbulnya komitmen kesepakatan dalam poin ketujuh perjanjian international yang disebut dengan MDG's (Millenium Development Goal's) 2015, yang disepakati pada September 2000. Komitmen International ini juga dijadikan salah satu acuan bagi Indonesia sebagai komitmen untuk mengembangkan sanitasi keberlanjutan yang layak. Sehingga pencapaian sasaran air bersih yang dicanangkan dalam MDG's diperlukan komitmen yang berkelanjutan dengan dikerahkan aspek sosial, ekonomi, dan teknologi (Cameron, 2013).

Pada tahun 2004, proporsi penduduk yang memiliki akses air bersih sebesar $73 \%$ dimana angka ini lebih rendah dari capaian target MDGs di Tahun 2015. Selain itu, angka prosentase tersebut ini belum membahas tentang kualitas fasilitas air bersih dan sanitasi yang layak (Susenas, 2004).

Salah satu masalah pokok yang dihadapi adalah berkurangnya tersedianya akses sumber air yang bersih adalah karena adanya pencemaran oleh limbah industri dan limbah domestik, sehingga beban dalam segi pengelolaan air bersihnya semakin meningkat. Selain itu belum meratanya pelayanan 
penyediaan air bersih, terutama pada daerah perdesaan. Sumber air bersih yang tersedia belum dapat dimanfaatkan secara maksimal. Maka dalam rangka penyediaan kebutuhan air bersih yang memenuhi syarat kesehatan, pemerintah RI mencanangkan program-program peningkatan penyediaan air bersih pada daerah perkotaan (urban) dan daerah pedesaan (rural) melalui minimisasi dan pemanfaatan sumber air yang ada secara optimal.

Kabupaten Malang merupakan salah satu Kabupaten yang terletak di kawasan di kawasan TNBTS (Taman Nasional Bromo Tengger Semeru) yang mana sebagai wilayah konservasi lingkungan dalam pelestarian hutan dan perlindungan air bersih. Sehingga memiliki potensi sumber air (mata air) yang berkualitas. Namun, masyarakat di sekitar Kabupaten Malang masih banyak yang tidak mendapatkan akses air bersih yang memadai karena kurang adanya akses air bersih. Dalam studi ini, akan dibahas mengenai kondisi daerah studi (Kabupaten Malang) dengan aspek sosial dan ekonomi yang melatarbelakangi keterbatasan akses air bersih tersebut. Selain itu, akan direncanakan sistem penyediaan air bersih yang diharapkan dapat menyelesaikan permasalahan krisis air bersih di kawasan Kabupaten Malang.

\section{GAMBARAN UMUM WILAYAH STUDI}

Lokasi penelitian dilakukan di Desa Argosari yang terletak di Kecamatan Jabung, Kabupaten Malang, Jawa Timur, Indonesia. Desa ini merupakan desa yang sudah terkena proyek sanitasi biogas, namun belum mendapat program air bersih dari pemerintah setempat.

Desa Argosari terletak di kawasan Pegunungan TNBTS (Taman Nasional Bromo Tengger Semeru) sebagai wilayah konservasi lingkungan dalam pelestarian hutan dan perlindungan air bersih yang meliputi kawasan Kabupaten Malang, Kabupaten Lumajang, Kabupaten Pasuruan dan Kabupaten Probolinggo. Secara geografis Desa Argosari berbatasan dengan Hutan Perhutani di sebelah timur dan 3 Desa yaitu: Desa Slamperejo; Desa Gading Kembar; Desa Kemantren. Kabupaten Malang merupakan salah satu daerah yang memiliki potensi konservasi alam yang sangat besar, karena merupakan daerah hulu air yang merupakan sumber air bagi daerah hilir (surabaya, gresik, dan lain lain).

Sebagian besar lahan difungsikan sebagai ladang, perkebunan dan hutan lindung. Pemukiman penduduk terletak berkelompok seperti yang ditunjukkan pada Gambar 1. Desa Argosari dibagi menjadi 3 dusun yaitu: Dusun Pateguhan, Dusun Gentong, dan Dusun Bendrong. 


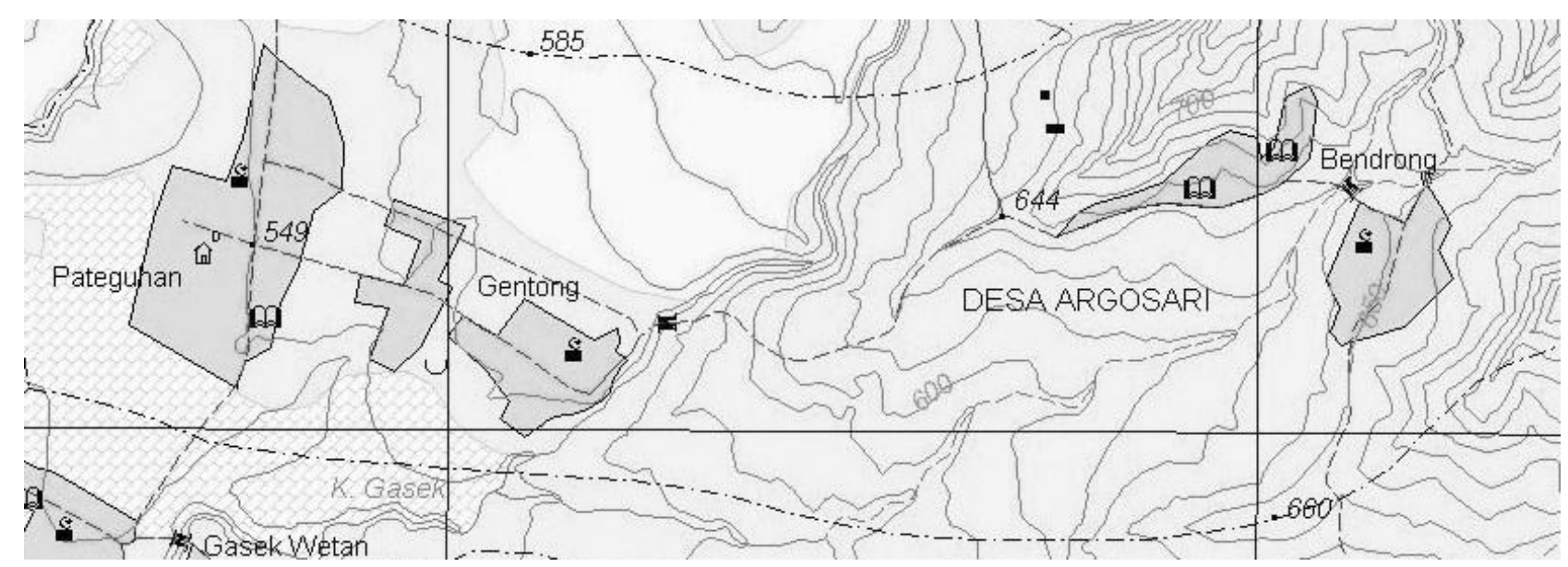

Gambar 1. Peta wilayah Desa Argosari

(Sumber: PU Kabupaten Malang)

Kondisi tanah sebagian besar datar, yang dapat dialiri saluran dari aliran Sungai Claket yang melewati Desa Argosari. Hal ini mendukung laju perekonomian masyarakat, terutama di bidang pertanian yang didukung oleh keberadaan tanahnya yang subur. Desa ini ditinggali sebesar \pm 2000 Kepala Keluarga (KK) (Laporan Desa Argosari 2009).

\section{METODOLOGI}

Penelitian dilakukan selama kurang lebih 1 bulan. Meliputi wawancara langsung dan penyebaran kuisioner di beberapa rumah tangga, Polindes, Puskesmas Kecamatan Jabung, Dinas Kesehatan Kabupaten Malang, hingga PU Cipta Karya Kabupaten Malang untuk mengetahui keadaan sebenarnya di lapangan. Ruang lingkup kuisioner rumah tangga dibagikan bagi penduduk yang sudah mendapatkan program sanitasi biogas yang akan dianalisa dampak perubahan perilaku terhadap kebutuhan air bersih.

Pengamatan kondisi eksisting dengan kajian sosial masyarakat kemudian dilanjutkan dengan analisis pengumpulan data. Evaluasi dilakukan dengan menganalisis penyediaan air bersih, pemanfaatan mata air, dan lembaga pemerintahan/komunitas masyarakat yang turut serta dalam pengelolaan air bersih. Kemudian dilakukan perecanaan teknologi dalam penyediaan air bersih yang diperkuat dengan studi pustaka. 


\section{HASIL DAN PEMBAHASAN}

\subsection{Analisis Kondisi Eksisting Fasilitas Air Bersih}

Menurut survei yang telah dilakukan pada tanggal 22-30 Juni 2010, didapatkan bahwa tingkat pendidikan di Desa Argosari sebanyak 72\% merupakan lulusan SD. Sedangkan lulusan SMP dan SMA berturut-turut sebanyak $16 \%$ dan 12\%. Jenis pekerjaan penduduk Desa Argosari adalah sebagian besar adalah peternak dan petani, yaitu sebanyak $68 \%$ dan $32 \%$. Hal ini membuktikan bahwa seluruh penduduk merupakan peternak. Dari hasil survei yang telah dilakukan, didapatkan hasil bahwa pendapatan bersih penduduk Desa Argosari adalah sebanyak Rp 500.000,- sebesar 72\%, lalu Rp 200.000 sebesar 16\%, dan Rp 1.000.000 sebesar 12\%. Pendapatan ini merupakan pendapatan untuk satu rumah dengan total per bulan yang sudah dikurangi untuk pengeluaran pembelian pakan ternak.

Kondisi ketersediaan air bersih di Desa Argosari sebenarnya tidak terlalu memprihatinkan. Dikenal dengan salah satu kawasan TNBTS (Taman Nasional Bromo Tengger Semeru), Desa Argosari menjadi salah satu kawasan dengan mata air yang berlimpah sekaligus dengan kualitas air bersih yang tergolong baik. Berikut merupakan salah satu mata air yang dimanfaatkan oleh masyarakat sekitar.
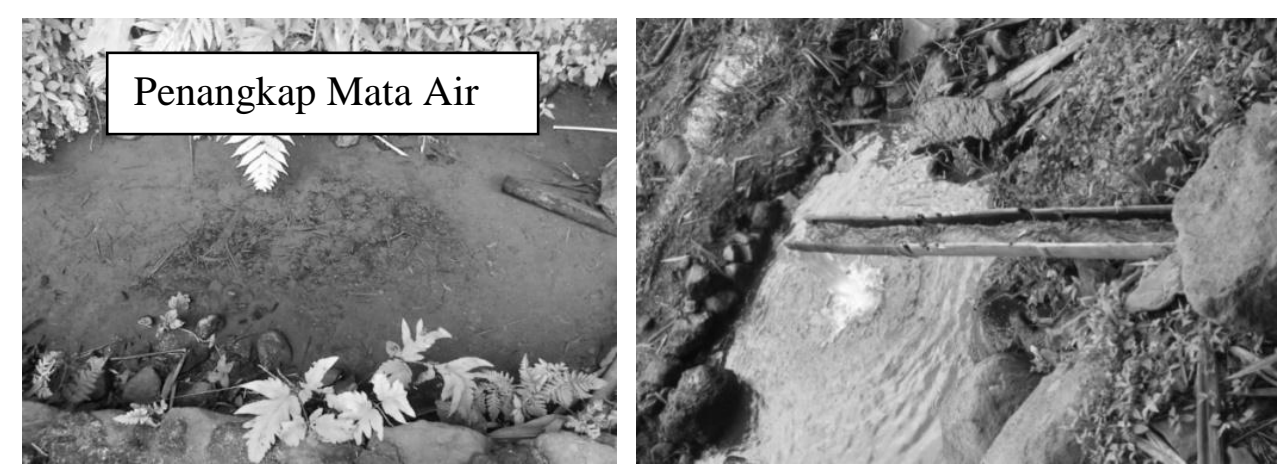

Gambar 2. Salah Satu Mata Air yang Dimanfaatkan Penduduk

(Sumber: Dokumentasi penelitian)

Salah satu permasalahan yang ada di Desa Argosari adalah sumber mata air yang jauh dari wilayah penduduk, dan tidak adanya sistem distribusi perpipaan yang baik untuk mengalirkan mata air tersebut. Sehingga hanya sebagian kecil masyarakat memanfaatkan mata air rembesan terdekat.

Mata air (rembesan) tersebut memiliki debit yang kecil sehingga hanya dapat dimanfaatkan oleh sekelompok penduduk disekitar mata air. Beberapa penduduk memasang pipa distribusi yang sangat 
sederhana ataupun harus membawa air dengan timba. Sedangkan penduduk yang tinggal jauh dari jangkauan mata air, harus berjalan beberapa kilometer untuk mendapat air bersih.
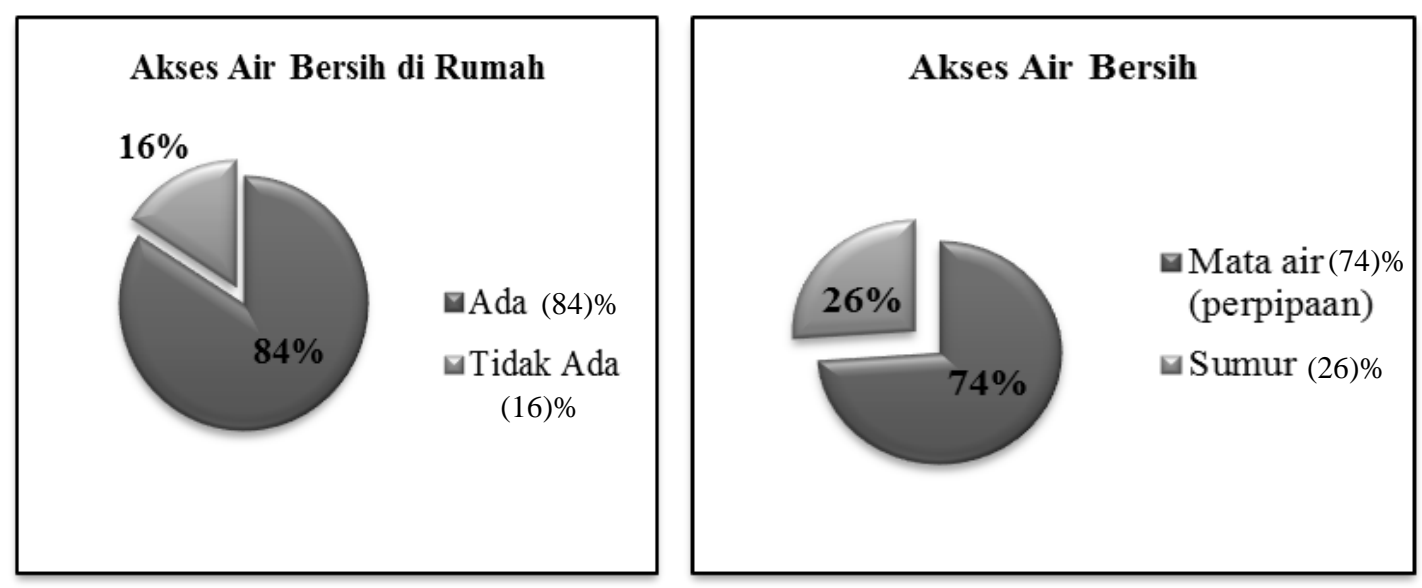

Gambar 3. Akses Air Bersih pengguna Biogas

(Sumber: Hasil Survey)

Dari responden pemanfaat biogas di Desa Argosari (dapat dilihat pada Gambar 3), bahwa penduduk yang sudah memiliki akses air bersih di rumah adalah $84 \%$, sedangkan sisanya $16 \%$ belum memiliki akses air bersih dirumah. Dari hasil data survei diatas dapat dilihat bahwa, sebagian besar penduduk dari pemanfaat biogas tersebut sudah memiliki akses air bersih. Hal ini dikarenakan oleh adanya kebutuhan operasional unit biogas yang membutuhkan air bersih sebagai pengencer limbah ternak.

Diantara penduduk yang sudah mendapat akses air bersih ternyata sebesar $26 \%$ menggunakan sumur. Sedangkan 74\% mendapat air bersih dari mata air (perpipaan). Beberapa responden yang jauh dari mata air dan sistem perpipaan, mengandalkan akses air bersih dengan menggunakan sumur dengan kedalaman minimal $20 \mathrm{~m}$. Hal ini menunjukkan bahwa akses air bersih menjadi suatu kebutuhan setelah adanya program sanitasi biogas rumah tangga. Kasus di Desa Argosari menunjukkan bahwa program sanitasi biogas yang sudah dijalankan telah meningkatkan perkembangan fasilitas air bersih.

Permasalahan air bersih lainnya adalah adanya sistem perpipaan mandiri penduduk yang tidak sesuai dengan kriteria ditribusi perpipaan air minum. Para penduduk secara langsung mengambil air dari sumber mata air dengan teknik perpipaan yang sangat sederhana dan tidak terencana dengan baik. Kebocoran pipa banyak terjadi, baik di sambungan antar pipa maupun retakan-retakan pipa akibat tertindih beban berat (akibat tidak tertanam di dalam tanah). Untuk lebih jelasnya dapat dilihat pada Gambar 4. 
Permasalahan semakin diperparah dengan kurangnya kesadaran masyarakat tentang efisiensi penggunaan air bersih. Sebagian besar masyarakat tidak memperhatikan keberlangsungan kuantitas air tanpa adanya usaha untuk melestarikan air yang ada. Pengamatan lapangan menunjukkan bahwa kebocoran pipa di percabangan pipa yang tidak ditutup sehingga air mengalir terus-menerus (dapat dilihat pada Gambar 4). Kurangnya kontrol terhadap sistem distribusi ini membuat air lebih banyak terbuang dari pada dimanfaatkan.

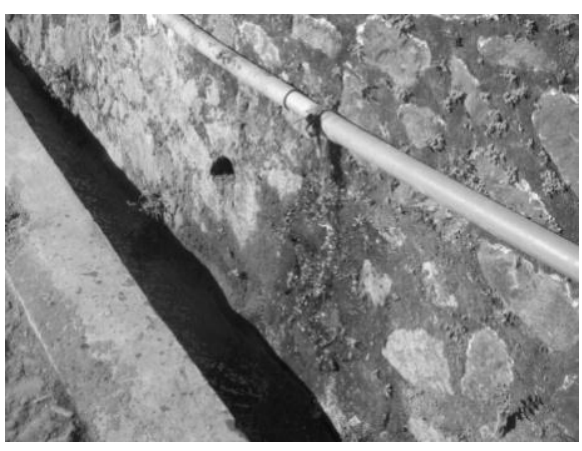

(a)

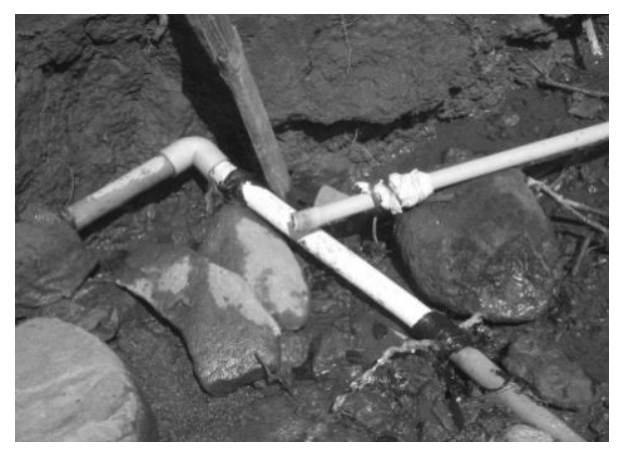

(b)

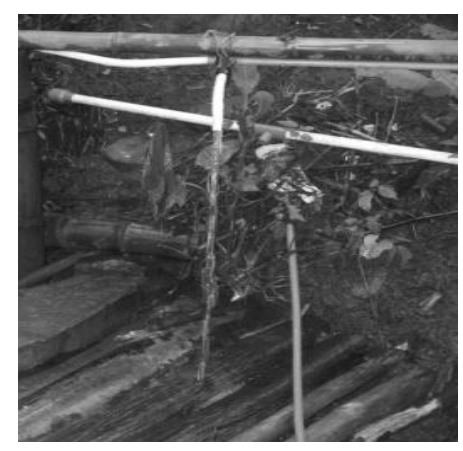

Gambar 4. Kondisi Perpipaan Desa Argosari; a). Perpipaan b).kebocoran pipa (Sumber: Dokumentasi penelitian)

\subsection{Perencanaan Sistem Air Bersih}

Kebutuhan dasar domestik ditentukan oleh adanya konsumen domestik, yang dapat diketahui dari data penduduk yang ada. Jenis pelayanan air memberikan pengaruh terhadap konsumsi air, yang dikenal dua kategori fasilitas penyediaan air minum, yaitu: Sambungan rumah (Kran disediakan sampai dalam rumah atau bangunan); Sambungan halaman (Kran disediakan sampai halaman rumah saja); Sambungan kran umum atau bak air yang dipakai bersama oleh sekelompok orang atau bangunan; Fasilitas non perpipaan, yang meliputi: sumur umum, mobil air, dan mata air.

Pada sistem distribusi masyarakat Desa Argosari ini akan direncanakan dengan fasilitas sambungan halaman. Untuk pipa yang akan dipasang sampai ke dalam rumah dibebankan ke masing-masing pemilik rumah sesuai dengan keinginan mereka yang beragam. Berdasarkan Desa Argosari (2010) sebanyak 1830 jiwa. Dengan proyeksi 10 tahun, diperkirakan jumlah penduduk meningkat sebanyak 20\%. Sehingga jumlah penduduk yang terlayani $=100 \%$ x $1.2=2196$ jiwa. Untuk perhitungan pembagian SR diasumsikan kebutuhan air 100L/jiwa/hari. Sehingga jumah sambungan rumah didapatkan 397 rumah dengan $\mathrm{Q}_{\text {domestik }}=2,54 \mathrm{~L} /$ detik. Kebutuhan non domestik ditentukan dari fasilitas yang dimiliki oleh daerah tersebut seperti sekolah, tempat ibadah, fasilitas tempat 
kesehatan, dan industri (2,54 L/detik). Sehingga kebutuhan air total (2,77 L/detik) dihitung dengan menjumlahkan kebutuhan air pada jam puncak dengan kebutuhan air untuk pemadam kebakaran (20\% dari debit total). Sehingga kebutuhan air total+kebocoran $=3,33 \mathrm{~L} / \mathrm{detik}$.

Untuk menghitung besarnya Qhm (Debit harian maksimum) digunakan faktor harian maksimum $\left(f_{\mathrm{hm}}\right)$ sebesar 1,2. Angka ini diperoleh dari analisa data kapasitas produksi dan kapasitas distribusi oleh mata air. Sebaiknya untuk menentukan faktor harian maksimum dilakukan penelitian khusus mengenai pola pemakaian air per hari. Dengan adanya pola pemakaian tersebut akan di dapat titik tertinggi pemakaian air per hari. Titik tersebut yang akan dijadikan faktor harian maksimum didapatkan dari fluktuasi pemakaian air dari PDAM sehingga didapatkan Qhm = 3,99 L/detik.

Untuk menghitung besarnya Qjm (Debit jam maksimum) digunakan faktor jam maksimum (fjm). Faktor jam maksimum ditentukan oleh kebiasaan dan pola aktivitas dari populasi yang menempati. Fluktuasi kebutuhan air timbul karena kegiatan masyarakat dalam penggunaan air yang berbeda pada tiap jam, hari, minggu, atau bulan. Dari keseluruhan aktivitas sehari tersebut dapat diketahui kondisi konsumsi rata-rata pada hari tersebut. Diasumsikan fluktuasi kebutuhan air jam puncak dalam sehari, sehingga diambil nilai 2sehingga didapatkan Qjm =6,66 L/detik. Jadi kebutuhan total dalam Desa Argosari adalah sebesar 6.66 L/detik. Gambar 5 merupakan peta sebaran penduduk dan mata air di Desa Argosari.

Sumber air bersih yang digunakan oleh masyarakat Desa Argosari adalah berasal dari mata air Bendo yang memiliki debit 8 liter/detik. Perencanaan kali ini menggunakan bangunan penangkap mata air (PMA) (broncaptering) untuk pemeliharaan kuantitas dan kualitas sumber mata air. Diasumsikan waktu detensi air pada PMA sebesar 60 detik, sehingga volume yang akan ditampung $=\mathrm{Q} \times \mathrm{td}=0.48 \mathrm{~m}^{3}$. Kemudian diasumsikan dimensi bak panjang $(\mathrm{p})=$ lebar $(\mathrm{l})$, sehingga didapatkan tbak (tinggi bak) $=0,48 \mathrm{~m}$. Jadi dimensi bangunan penangkap mata air tersebut adalah $1 \mathrm{~m} \times 1 \mathrm{~m} \times 0.5 \mathrm{~m}$ (pxlxt).

Mata air Bendo ini tidak hanya dimanfaatkan untuk memenuhi kebutuhan air bersih masyarakat namun digunakan untuk mengairi irigasi ladang Desa Argosari. Oleh karena itu pada bangunan penangkap mata air ini akan dibuat 3 pipa overflow dengan kebutuhan air yang bervariasi: (a) Digunakan kebutuhan air harian rata-rata (Qrh= 3.33 liter/detik), dengan waktu detensi 60 detik dan dimensi $\mathrm{P}=\mathrm{L}$ sehingga ketinggian pipa overflow $\mathrm{t}=0.2 \mathrm{~m}$; (b) Digunakan kebutuhan air harian maksimum $(\mathrm{Qhm}=3.99$ liter/detik), sehingga ketinggian pipa overflow $\mathrm{t}=0.24 \mathrm{~m}$; (c) Digunakan kebutuhan air jam maksimum (Qjm= 6.66 liter/detik), sehingga ketinggian pipa overflow $\mathrm{t}=0.4 \mathrm{~m}$. 


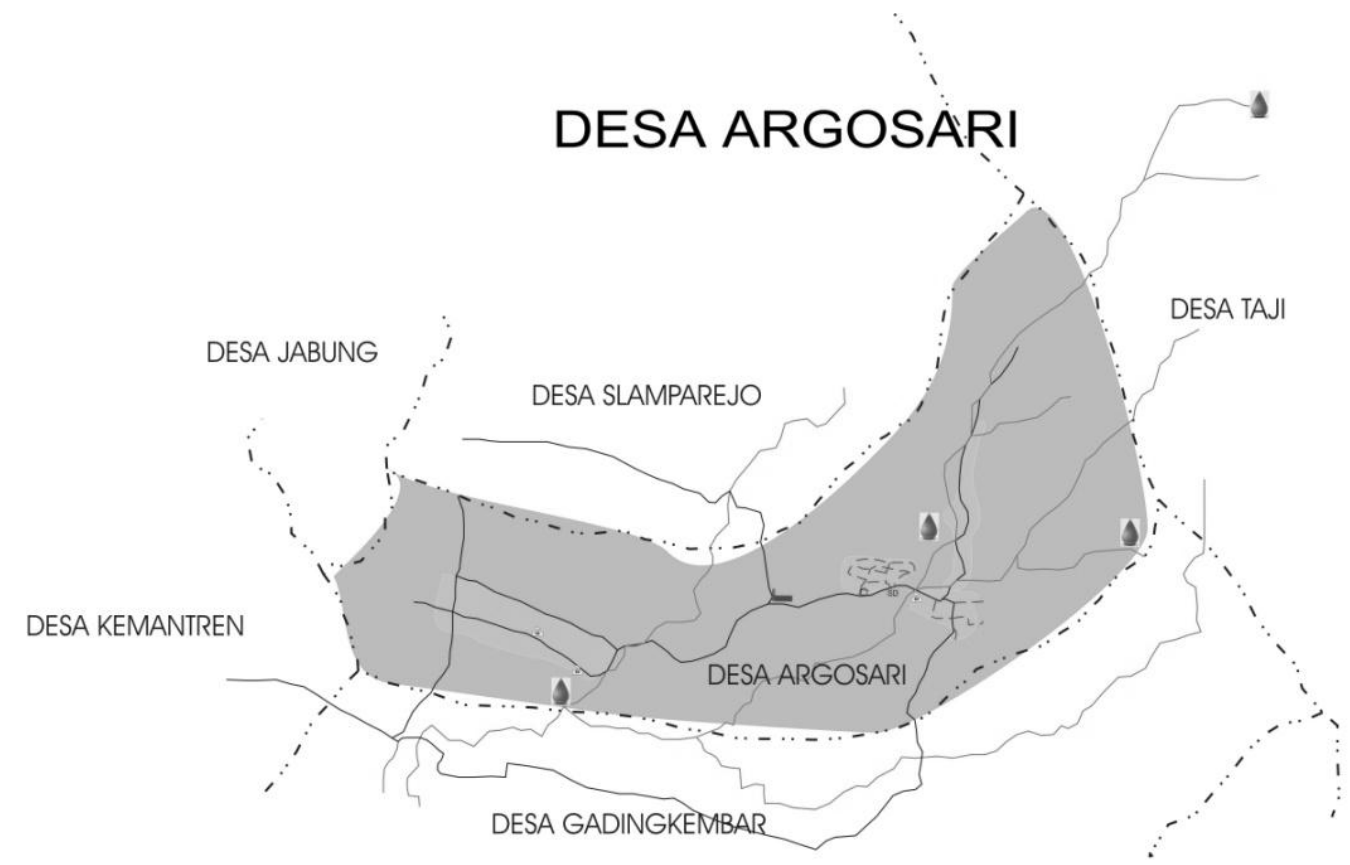

Gambar 5. Peta Desa Argosari

(Sumber: Desa Argosari)

Analisis perencanaan sistem distribusi air bersih menggunakan software EPANET. Seluruh data elevasi, titik junction (node), debit, panjang pipa dan diameter pipa dimasukkan ke dalam software. Data diameter yang digunakan adalah diameter dalam dan yang sesuai dipasaran. Dalam tugas perencanaan ini digunakan pipa PVC Maspion dengan kriteria S12, dengan arti kekuatan pipa tersebut adalah 8 bar. Hasil Analisa Epanet pada proyeksi tahun 2020 yang sudah sukses dapat dilihat pada Gambar 6 berikut ini.
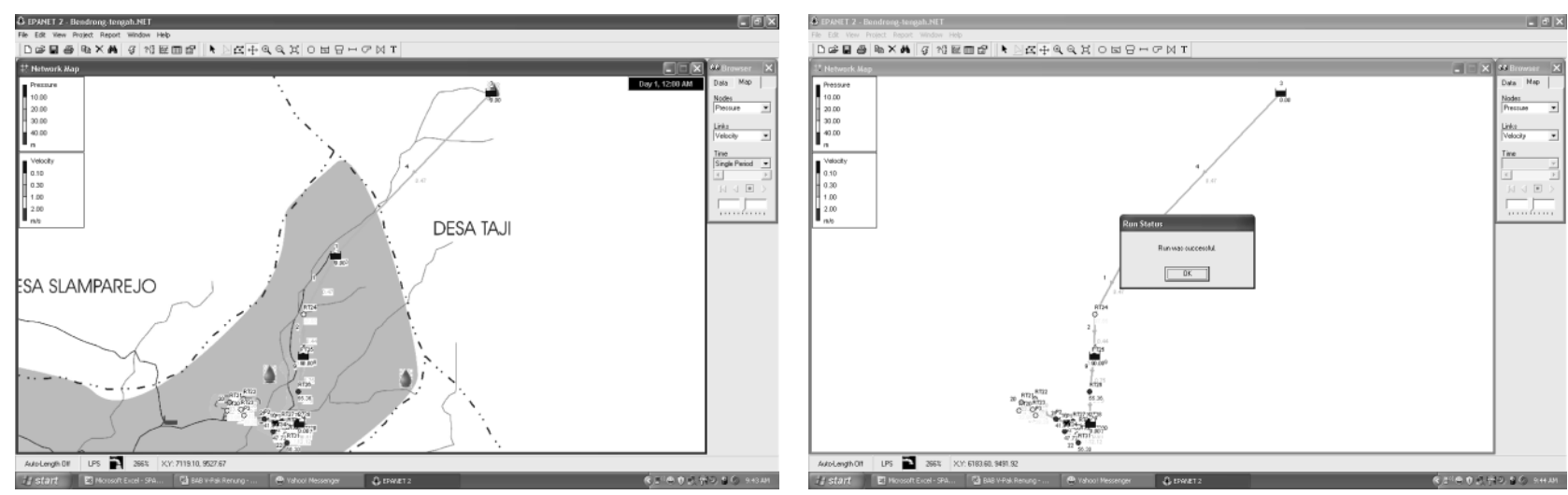

Gambar 6. Sistem jaringan Loop

(Sumber: Hasil analisa dengan software Epanet) 
Tabel 1 berikut adalah tabel hasil perhitungan pressure dan head yang dihasilkan dari perencanaan sistem distribusi Desa Argosari.

Tabel 1. Network Node Epanet

\begin{tabular}{|c|c|c|c|c|c|}
\hline \multicolumn{6}{|c|}{ Network Table - Nodes } \\
\hline Node ID & $\begin{array}{c}\text { Elevation } \\
\text { (m) }\end{array}$ & $\begin{array}{c}\text { Base } \\
\text { Demand } \\
\text { (LPS) }\end{array}$ & $\begin{array}{l}\text { Demand } \\
\text { (LPS) }\end{array}$ & $\begin{array}{c}\text { Head } \\
(\mathbf{m})\end{array}$ & $\begin{array}{l}\text { Pressure } \\
\quad(\mathbf{m})\end{array}$ \\
\hline Junc P1 & 666 & 0 & 0 & 708.39 & 42.39 \\
\hline Junc RT27 & 666 & 0.15 & 0.18 & 708.84 & 42.84 \\
\hline Junc RT32 & 670 & 0.18 & 0.22 & 709.12 & 39.12 \\
\hline Junc RT33 & 675 & 0.15 & 0.18 & 709.45 & 34.45 \\
\hline Junc RT24 & 790 & 0.18 & 0.22 & 827.55 & 37.55 \\
\hline Junc RT25 & 750 & 0.14 & 0.17 & 759.9 & 9.9 \\
\hline Junc RT26 & 700 & 0.18 & 0.22 & 755.36 & 55.36 \\
\hline Junc RT2930 & 690 & 0.48 & 0.58 & 702.12 & 12.12 \\
\hline Junc RT34 & 660 & 0.25 & 0.3 & 707.72 & 47.72 \\
\hline Junc RT20 & 670 & 0.28 & 0.34 & 703.96 & 33.96 \\
\hline Junc RT21 & 680 & 0.16 & 0.19 & 703.33 & 23.33 \\
\hline Junc RT22 & 680 & 0.21 & 0.25 & 703.98 & 23.98 \\
\hline Junc RT23 & 670 & 0.1 & 0.12 & 705.02 & 35.02 \\
\hline Junc RT31 & 650 & 0.36 & 0.43 & 706.3 & 56.3 \\
\hline Junc RT28 & 700 & 0.26 & 0.31 & 709.37 & 9.37 \\
\hline Junc P2 & 666 & 0 & 0 & 707.64 & 41.64 \\
\hline Junc P3 & 666 & 0 & 0 & 705.39 & 39.39 \\
\hline Junc P4 & 700 & 2.58 & 3.1 & 751.27 & 51.27 \\
\hline Junc 4 & 830 & 3.08 & 3.7 & 893 & 63 \\
\hline Junc 7 & 760 & 2.9 & 3.48 & 825.99 & 65.99 \\
\hline Resvr 1 & 830 & \#N/A & -3.7 & 830 & 0 \\
\hline Resvr 2 & 710 & \#N/A & -3.1 & 710 & 0 \\
\hline Resvr 3 & 900 & \#N/A & -3.7 & 900 & 0 \\
\hline Resvr 4 & 760 & \#N/A & -3.48 & 760 & 0 \\
\hline
\end{tabular}

Sumber: Hasil analisa dengan software Epanet 
Tabel 2 berikut ini adalah tabel diameter yang digunakan untuk sistem distribusi Desa Argosari.

Tabel 2. Network Link Epanet Running Success

\begin{tabular}{|c|c|c|c|c|c|c|}
\hline \multicolumn{7}{|c|}{ Network Table - Links } \\
\hline Link ID & $\begin{array}{c}\text { Length } \\
\text { (m) }\end{array}$ & $\begin{array}{c}\text { Diameter } \\
(\mathbf{m m})\end{array}$ & Roughness & $\begin{array}{c}\text { Flow } \\
\text { (LPS) }\end{array}$ & $\begin{array}{c}\text { Velocity } \\
(\mathrm{m} / \mathrm{s})\end{array}$ & $\begin{array}{c}\text { Unit } \\
\text { Headloss } \\
(\mathbf{m} / \mathbf{k m})\end{array}$ \\
\hline Pipe 1 & 700 & 100 & 120 & 3.7 & 0.47 & 3.5 \\
\hline Pipe 2 & 500 & 100 & 120 & 3.48 & 0.44 & 3.13 \\
\hline Pipe 5 & 100 & 75 & 120 & 2.21 & 0.5 & 5.47 \\
\hline Pipe 8 & 50 & 50 & 120 & 0.85 & 0.43 & 6.75 \\
\hline Pipe 14 & 200 & 30 & 120 & 0.58 & 0.81 & 39.41 \\
\hline Pipe 15 & 50 & 50 & 120 & 1.18 & 0.6 & 12.29 \\
\hline Pipe 16 & 50 & 50 & 120 & 1 & 0.51 & 9.03 \\
\hline Pipe 19 & 100 & 38 & 120 & 0.53 & 0.47 & 10.61 \\
\hline Pipe 20 & 50 & 25 & 120 & 0.19 & 0.39 & 12.52 \\
\hline Pipe 21 & 50 & 25 & 120 & 0.25 & 0.51 & 20.72 \\
\hline Pipe 22 & 50 & 25 & 120 & 0.43 & 0.88 & 56.23 \\
\hline Pipe 23 & 50 & 30 & 120 & 0.31 & 0.44 & 12.66 \\
\hline Pipe 24 & 100 & 25 & 120 & 0.2 & 0.41 & 13.95 \\
\hline Pipe 25 & 50 & 19 & 120 & -0.1 & 0.34 & 13.33 \\
\hline Pipe 26 & 100 & 50 & 120 & 0.9 & 0.46 & 7.48 \\
\hline Pipe 27 & 300 & 50 & 120 & 0.9 & 0.46 & 7.48 \\
\hline Pipe 28 & 50 & 50 & 120 & 0.9 & 0.46 & 7.48 \\
\hline Pipe 4 & 2000 & 100 & 120 & 3.7 & 0.47 & 3.5 \\
\hline Pipe 7 & 10 & 25 & 120 & 0.17 & 0.34 & 9.78 \\
\hline Pipe 9 & 400 & 75 & 120 & 3.31 & 0.75 & 11.59 \\
\hline Pipe 10 & 400 & 75 & 120 & 3.1 & 0.7 & 10.23 \\
\hline
\end{tabular}

Sumber: Hasil analisa dengan software Epanet

Pada perencanaan sistem distribusi air bersih ini direncanakan satu buah bangunan penangkap air minum, 1 buah bak pelepas tekan dan 2 buah reservoar. Dibutuhkan satu buah bak pelepas tekan yang akan diletakkan diantara bangunan penangkap mata air dan reservoar 1 dikarenakan beda tinggi yang amat besar antara kedua bangunan tersebut. Dengan data perencanaan sebagai berikut: $\mathrm{L}=2700 \mathrm{~m} ; \mathrm{DH}=110 \mathrm{~m} ; \mathrm{Qrh}=3.33$ liter/detik; $\mathrm{C}=120$, menggunakan rumus Hazen Williams:

Keterangan : $\mathrm{L}=$ panjang pipa $(\mathrm{m})$

$$
H f=\frac{L^{*} Q^{1.85}}{\left(0.00155^{*} c^{*} d^{2.63}\right)^{1.85}}
$$$$
\mathrm{Q}=\text { debit pipa }\left(\mathrm{m}^{3} / \text { detik}\right)
$$$$
\mathrm{C}=\text { koefisien kekasaran pipa }
$$$$
\mathrm{D}=\text { diameter pipa }(\mathrm{m})
$$ 
Jika digunakan $\mathrm{d}=10 \mathrm{~cm}$, maka $\mathrm{Hf}=7.64 \mathrm{~m}$ dan sisa head yang terjadi $=110 \mathrm{~m}-7.64 \mathrm{~m}=102.36$ m. Dari perencanaan diatas didapatkan sisa head $102.36 \mathrm{~m}$. Pada perencanaan sistem distribusi air bersih masyarakat Desa Argosari ini digunakan pipa PVC S 12 yang berarti pipa tersebut mampu menahan tekanan maksimum $80 \mathrm{~m}$. Jika sisa head $102.36 \mathrm{~m}$ dibiarkan terjadi di dalam pipa tersebut, maka pipa akan pecah. Untuk menghindari hal tersebut, maka direncanakan bak pelepas tekan yang diletakkan sebelum reservoar 1 atau pada beda tinggi maksimum $80 \mathrm{~m}$ dari bangunan penangkap mata air. Data perencanaan sebagai berikut: L = $2000 \mathrm{~m}$; DH = $70 \mathrm{~m}$; Qrh = 3.33 liter/detik; $\mathrm{C}=$ 120. Jika digunakan $\mathrm{d}=10 \mathrm{~cm}$, maka, $\mathrm{Hf}=5.66 \mathrm{~m}$. Sisa head yang terjadi $=70 \mathrm{~m}-5.66 \mathrm{~m}=64.34$ m. Bila menggunakan debit jam puncak (Qjm $=6.66$ liter/detik); $\mathrm{d}=10 \mathrm{~cm}$ maka, $\mathrm{Hf}=20.41 \mathrm{~m}$. Sisa head yang terjadi $=70 \mathrm{~m}-20.41 \mathrm{~m}=49.59 \mathrm{~m}$.

Dari hasil perhitungan sisa head yang terjadi pada bak pelepas tekan di atas, dapat dilihat bahwa sisa head maksimum yang terjadi adalah $64.34 \mathrm{~m}$ dan sisa head minimum adalah $49.59 \mathrm{~m}$. Angka ini cukup aman untuk ditahan oleh pipa dan juga untuk distribusinya.

\subsection{BOQ dan RAB}

\section{Pengadaan dan Pemasangan Pipa Lengkap dengan Aksesories}

Menurut kondisi eksisiting Desa Argosari maka dibutuhkan 3 jembatan pipa dengan menggunakan 3 perlintasan 3 Pipa GI dengan diameter $4 \mathrm{~cm}$. Tabel 3 dan Tabel 4 merupakan perhitungan RAB pipa dan aksesorisnya berdasarkan dari kebutuhan pipa dengan program epanet dan disesuaikan dengan HSPK Kabupaten Malang.

Tabel 3. RAB Pipa

\begin{tabular}{|r|r|r|r|r|r|}
\hline $\begin{array}{c}\text { Diameter } \\
\text { Pipa } \\
\text { (mm) }\end{array}$ & $\begin{array}{c}\text { Panjang } \\
\text { Pipa } \\
\text { (m) }\end{array}$ & $\begin{array}{c}\text { Diameter } \\
\text { Pipa } \\
\text { (inch) }\end{array}$ & $\begin{array}{c}\text { Jumlah } \\
\text { Pipa } \\
\text { batang }\end{array}$ & $\begin{array}{c}\text { Harga } \\
\text { Pipa/batang } \\
\text { (Rp) }\end{array}$ & $\begin{array}{c}\text { Harga Pipa } \\
\text { (Rp) }\end{array}$ \\
\hline 100 & 3000 & 4 & 750 & 268.000 & 201.000 .000 \\
\hline 75 & 100 & 3 & 25 & 140.000 & 3.500 .000 \\
\hline 50 & 600 & 2 & 150 & 100.555 & 15.083 .250 \\
\hline 38 & 350 & 1,52 & 88 & 55.000 & 4.840 .000 \\
\hline 25 & 300 & 1 & 75 & 27.700 & 2.077 .500 \\
\hline
\end{tabular}

Sumber: Hasil perhitungan (berdasarkan harga pipa tertinggi HSPK Kabupaten) 
Tabel 4. BOQ Aksesoris Pipa

\begin{tabular}{|r|r|r|r|r|}
\hline $\begin{array}{c}\text { D } \\
(\mathbf{m m})\end{array}$ & $\begin{array}{c}\text { Panjang } \\
(\mathbf{m})\end{array}$ & $\begin{array}{c}\text { Satuan } \\
\text { Batang } \\
(\mathbf{m})\end{array}$ & $\begin{array}{c}\text { Jumlah } \\
\text { Pipa } \\
\text { (buah) }\end{array}$ & $\begin{array}{c}\text { Jumlah } \\
\text { Socket } \\
\text { (buah) }\end{array}$ \\
\hline 100 & 3200 & 4 & 800 & 800 \\
\hline 75 & 900 & 4 & 225 & 225 \\
\hline 50 & 600 & 4 & 150 & 150 \\
\hline 38 & 100 & 4 & 25 & 25 \\
\hline 30 & 250 & 4 & 62,5 & 63 \\
\hline 25 & 260 & 4 & 65 & 65 \\
\hline
\end{tabular}

Sumber: Hasil perhitungan

Tabel 5 dan Tabel 6 merupakan perhitungan BOQ (Bill of Quantity) dan RAB (Rencana Anggaran Biaya). 

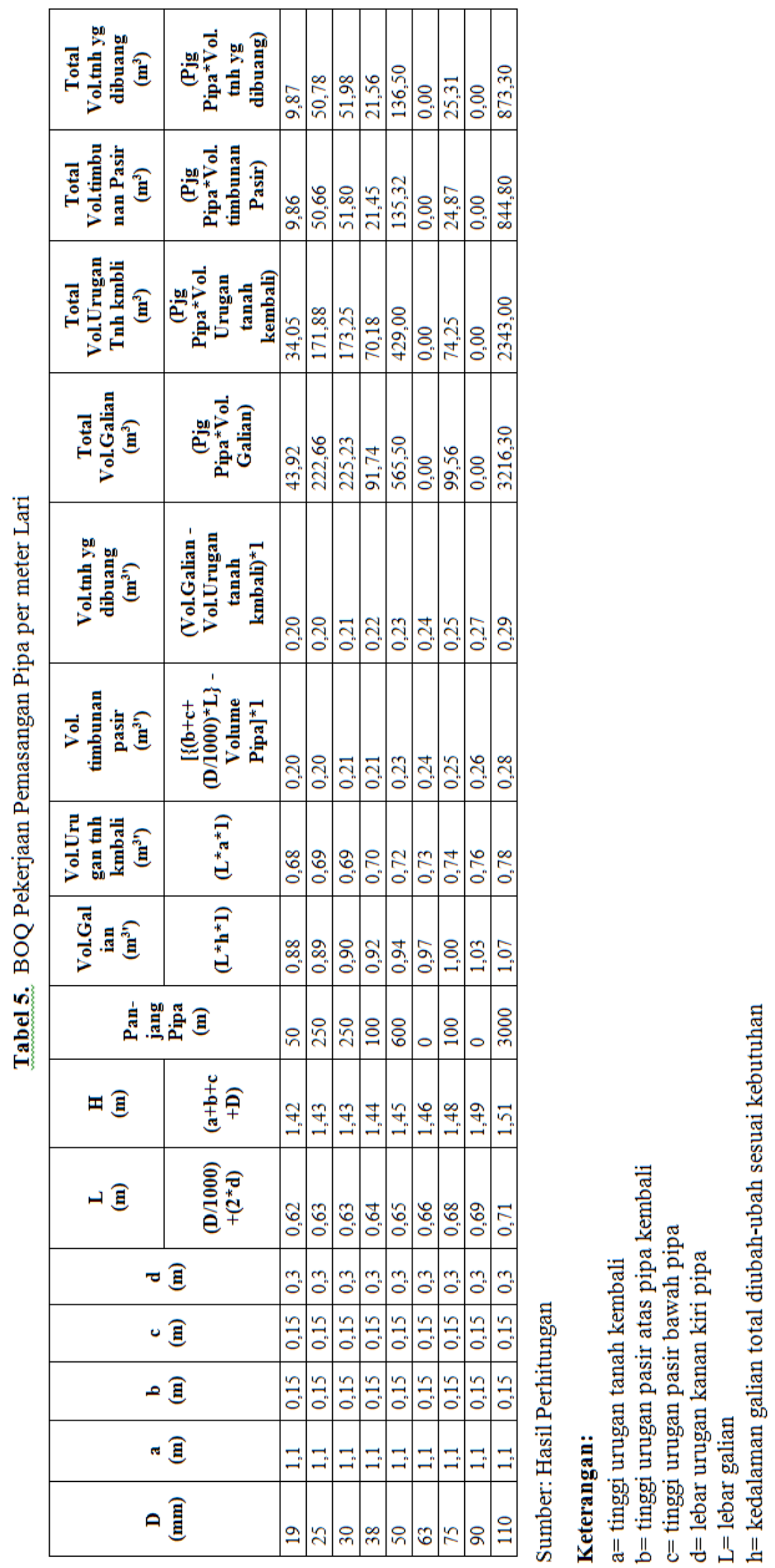


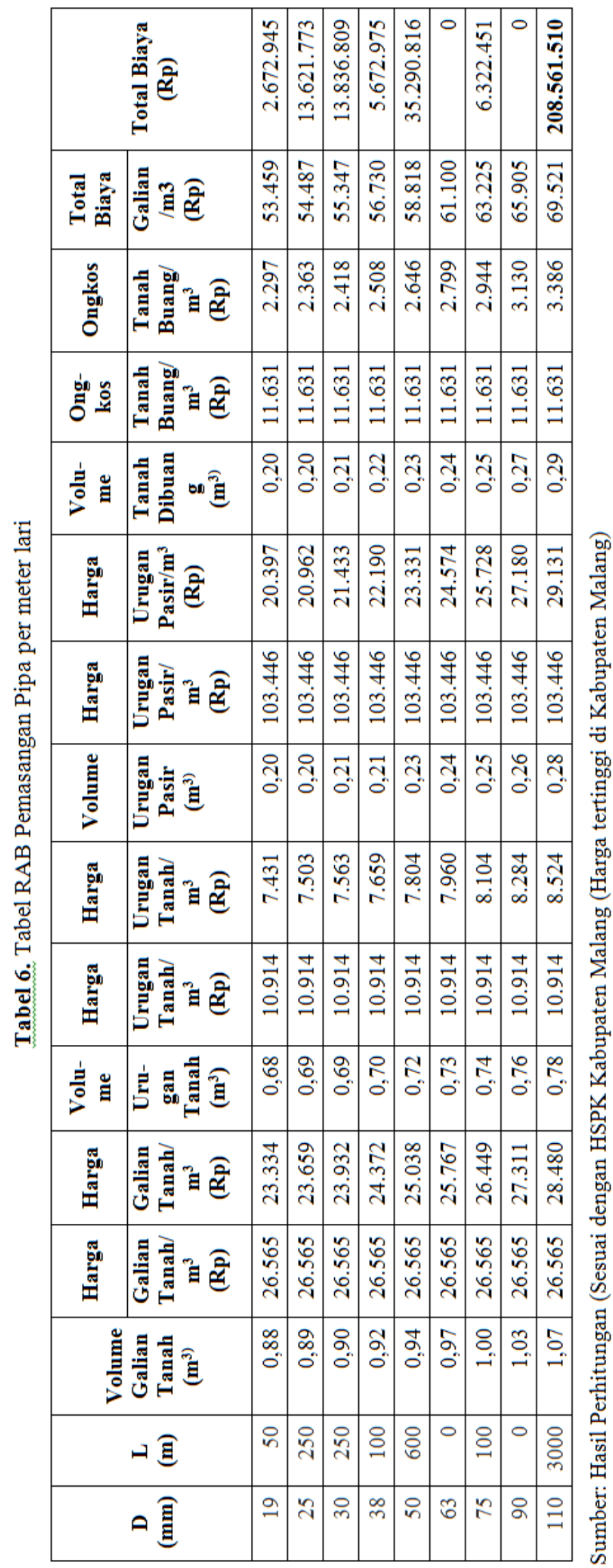




\section{DAFTAR PUSTAKA}

Badan Perencanaan Nasional (Bappenas). 2010. Laporan Pencapaian Tujuan Pembangunan Milenium di Indonesia.

Cameron, Lisa., Shah, Manisha., Olivia, Susan. 2013. Impact Evaluation of a Large-Scale Rural Sanitation Project in Indonesia. World Bank

El Haq, Putut Sambang. 2010. Potensi Tinja Manusia Sebagai Penghasil Biogas. Jurusan Teknik Lingkungan FTSP ITS.

Harga Satuan Pokok Kerja (HSPK) Kabupaten Malang. 2010.

Haris, M. 2007. Studi Kinerja Unit Pengolahan Air Limbah Anaerobik Baffled Reactor (ABR) Pada Program SANIMAS di Mojokerto. Jurusan Teknik Lingkungan FTSP ITS.

Laporan Desa Argosari. 2009.

Laporan Millenium Development Goals 2015. 2012. United Nations

Penyebab, Sebab dan Akibat Pencemaran Lingkungan Pada Air dan Tanah - Kesehatan Lingkungan - Ilmu Sains Biologi. Mon, 12/06/2006 - 2:27pm — godam64

PU Cipta Karya. 2010.Petunjuk Teknis PelaksanaanPengembangan SPAM Sederhana. PU Cipta Karya Kabupaten Malang

Profil Sanitasi Indonesia, 2004

Progress on Drinking Water and Sanitation: 2012 Update. 2012. UNICEF and World Health Organization

Progress on Sanitation and Drinking-water - 2013 update. 2013. UNICEF and World Health Organization

Rifa'i, M. Masykur. 2009. Evaluasi dan Pengembangan Sistem Penyediaan Air Bersih Perdesaan Kecematan Jatirejo Kabupaten Mojokerto. Jurusan Teknik Lingkungan FTSP ITS.

Soemirat, Juli. 2000. Kesehatan Lingkungan. Gajah Mada University Press : Jogjakarta

Survei Sosial Ekonomi Nasional (SUSENAS), 2004 